\section{The Financial Situation}

\section{E.W.A. Lingeman, Amsterdam}

(Treasurer of EPS)

Every year the financial situation of our Society is examined by external auditors, KPMG Fides Peat. In November last year they presented their report on the year 1987 and in Table 1 the profit and loss account (in condensed form) from that report is compared with the three preceding years. It will be seen there that the years 1987 and 1985 ended with a loss, the years 1986 and 1984 with a profit.

The CHARGES are subdivised into 4 items:

Salaries including salaries and social charges and auxiliary salaries; Europhysics News including printing, editorial expenses and distribution; Cost of the secretariat including travel expenses, rent, maintenance, telephone, mailing, office material, duplication, general administration, printing of the EPS poster and promotion of publishing activities: Expenses for committees etc. including expenses for Executive Committee meetings, Council, Divisions and the production of Europhysics Conference Abstracts (ECA).

The INCOME is subdivided into the well known membership categories, gifts and donations, the income from Europhysics News and different other incomes including revenue from advertisements, sales of publications and exchange differences.

One sees that our Society oscillates between making a profit and making a loss, but at the beginning of 1988, the accumulated losses reached a height of $155 \mathrm{k}$ SFR.

\begin{tabular}{|c|c|c|c|c|}
\hline \multicolumn{5}{|c|}{ Profit \& Loss account (From External Auditors Reports) } \\
\hline As at 31 December & 1987 & 1986 & 1985 & 1984 \\
\hline \multicolumn{5}{|l|}{ CHARGES } \\
\hline Salaries & 460175.75 & 356837.80 & 328830.25 & 306662.85 \\
\hline Europhysics News & 144836.50 & 137463.10 & 149128.65 & 132444.45 \\
\hline Cost Secretariat & 141068.50 & 138483.30 & 118170.75 & 115882.68 \\
\hline \multirow[t]{3}{*}{ Expenses for Committees etc. } & 65169.22 & 48519.80 & 47416.10 & 49932.55 \\
\hline & 811249.97 & 681304.00 & 643545.75 & 604922.53 \\
\hline & 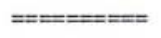 & 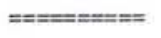 & $===x===$ & $====$ \\
\hline \multicolumn{5}{|l|}{ INCOME } \\
\hline Membership fees Art. 4a) & 11220.00 & 9084.00 & 8880.00 & 8520.00 \\
\hline Membership fees Art. 4c) & 123772.00 & 108870.00 & 93760.00 & 99000.00 \\
\hline Membership fees Art. 4c) & 2926.00 & 1683.00 & 320.00 & 220.00 \\
\hline Membership fees Art. 4d) & 10065.00 & 7962.50 & 5350.00 & 3850.00 \\
\hline Membership fees Art. 4b) & 245108.20 & 249105.40 & 224663.00 & 222314.00 \\
\hline Associate Members & 177318.00 & 166786.86 & 175378.70 & 171646.60 \\
\hline Gifts \& Donations & 0.00 & 23800.00 & 0.00 & 0.00 \\
\hline Europhysics News & 40086.40 & 45463.40 & 44490.30 & 47354.10 \\
\hline Different other income & 65166.93 & 78821.38 & 57091.83 & 61126.27 \\
\hline \multirow{4}{*}{ Reversal Special Development Fund } & 675662.52 & 691576.54 & 609933.83 & 614030.97 \\
\hline & & & 10000.00 & \\
\hline & 675662.53 & 691576.54 & 619933.83 & 614030.97 \\
\hline & 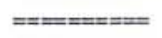 & $==x=m=e=$ & $=m==0=$ & $==0=0=$ \\
\hline Net Profit (Loss) & (135 587.44) & 10272.54 & $(23611.92)$ & 9108.44 \\
\hline$==e==e=$ & $==0=x=$ & $==\mathrm{enan}=\mathrm{e}=$ & $=$ & $m=0=$ \\
\hline
\end{tabular}

For this year, the rise in unit fee allows us to show a profit of 6380 SFR, which will make little further impression on our accumulated losses.

Why a lower surplus in 1989 than in 1988 ? Every year EPS has its financial surprises. In 1986 the HEPP (High Energy and Particle Physics) Division donated a sub stantial sum to the Society (see first Table). Last year the German Physical Society realised it had more members than were known to the Secretariat in Geneva and it made up the difference. Moreover, 1988 expenses were much lower than expected as the Council meeting in Dresden was cheaper, there was no meeting with the Associate Members and Division Chairmen and no EPS poster was printed.

\section{So what to do?}

Reduce expenses: The Advisory Committee on Finances went with a toothcomb through the expenses and could not indicate any item to be reduced without stopping some of our main activities.

Increase income: The income of EPS can be divided into the three main membership categories: 1. Member Societies, 2. Associate Members, 3 . Individual Members. Category 1 ( 268 k SFR) provides the main income of the Society, but is essentially fixed. Category 2 (185.3 k SFR) can increase if a considerable effort is put in by Individual Members to convince industrial firms to join the Associate Members for which the minimum fee is now only $2 \mathrm{k}$ SFR. The last category 3 ( $144.5 \mathrm{k} \mathrm{SFR})$ is the most promising. Before the great clean-up of non-paying members, EPS had more than 5000 Individual Ordinary Members. At the moment, EPS has of the order of 3000 paying IOM's. Based merely on the old potential of 5000 physicists it must be possible to double the present number If each IOM brings in only one colleague as a present to the 20th birthday of the EPS, EPS can look forward with optimism to the next twenty years.

\section{How did this happen?}

We are all well aware of the success of the latest EPS venture, the launching of Europhysics Letters in 1987. To be able to do this however EPS had to invest in extra manpower. This can be seen from the difference in salaries between 1987 and 1986 of more than $100 \mathrm{k}$ SFR. This was a temporary situation and those costs are now carried by the journal. However there was a continuing problem and to cover the creeping losses, the Executive Committee proposed to Council to increase the unit fee from 11 to 12 SFR. Council agreed to this proposal last March and the rise becomes effective in 1989.

\section{How did we fare in 1988 and what will happen this year?}

In Table 2 the budgets for the years 1987, 1988 and 1989 for convertible currency only are presented and compared. The net loss for 1987 in this Table is lower than in the first Table because amortization, normally included in the profit and loss account, does not appear in the budget.

The year 1988 ended with a profit of 35 k SFR which will be used to reduce our debts.

\begin{tabular}{|c|c|c|c|}
\hline \multicolumn{4}{|c|}{ Budgets for 1987,1988 and $1989^{*}$} \\
\hline & 1987 & 1988 & 1989 \\
\hline \multicolumn{4}{|l|}{ CHARGES } \\
\hline Salaries & 460175.75 & 350000.00 & 370000.00 \\
\hline Europhysics News & 144836.50 & 147280.00 & 148500.00 \\
\hline Cost of Secretariat & 141068.40 & 125000.00 & 134500.00 \\
\hline \multirow[t]{3}{*}{ Cost Committees etc. } & 39677.00 & 28000.00 & 34000.00 \\
\hline & 785757.75 & 650283.00 & 687000.00 \\
\hline & 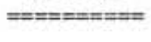 & $==2=x=0$ & $==-==-==$ \\
\hline \multicolumn{4}{|l|}{ INCOME } \\
\hline Membership fees Art. 4a) & 11220.00 & 10164.00 & 10080 \\
\hline Membership fees Art. 4c) & 123772.00 & 123200.00 & 124800.00 \\
\hline Membership fees Art. 4d) & 10065.00 & 8800.00 & 9600.00 \\
\hline Membership fees Art. 4b) & 245108.20 & 260000.00 & 268000.00 \\
\hline Associate Members & 177318.00 & 185300.00 & 186000.00 \\
\hline Gifts \& Donations & 0.00 & 0.00 & 0.00 \\
\hline Europhysics News & 40086.40 & 42104.00 & 46400.00 \\
\hline \multirow[t]{2}{*}{ Different other income } & 65166.93 & 56000.00 & 48500.00 \\
\hline & 672736.53 & 685568.00 & 693380.00 \\
\hline Net Profit (Loss) & (113 021.22) & 35285.00 & 6380.00 \\
\hline
\end{tabular}

